\title{
Economic Analysis of Milk Production in Satara District of Maharashtra
}

\author{
S. L. Jadhav ${ }^{1}$, K. V. Deshmukh ${ }^{2}$ and R. D. Shelke ${ }^{1^{*}}$ \\ ${ }^{1}$ Department of Agricultural Economics, COA, Latur, India \\ ${ }^{2}$ Department of Agricultural Economics, COA, Parbhani, India \\ *Corresponding author
}

\section{A B S T R A C T}

\begin{tabular}{|l|}
\hline Ke y w o r d s \\
Crossbreed cow \\
milk production, \\
Cost and returns, \\
Variable cost
\end{tabular}

\section{Introduction}

Basically India is an agricultural country and livestock sector is an integral part of the agriculture. It is the back-bone of India's economy in the form of income, employment and foreign exchange earnings. It is estimated that dairying sector alone is contributing $15 \%$ of the Gross National Income. The growth of this livestock sector is much faster $(6-8 \%)$ than core agriculture itself $(2.3 \%)$ Dairy itself has a growth of $5-6 \%$ per annum. In the global Scenario India is the topper in milk production, has third position in egg and fifth in chicken production. In livestock sector 16.44 million people engaged in this sector. In
The present study was conducted to find out cost and returns obtained from the crossbreed cow milk production in Satara district of Maharashtra. Multistage sampling technique was used for this study. For this study Satara district was purposively selected. In Satara district six villages were selected randomly from the two tehsils in satara district. The 90 sample farmers were selected from the six villages on the basis of milk production obtained by the farmers. The 90 farmers was categorized as small -2cow), medium (3-5cow), large (5-10 cow) on the basis of number of crossbreed present. The tabular analysis was used for calculating the cost and returns obtained maint me and $19 \%$ cost was on fixed capital. The gross returns obtained from small, medium and large farmer was Rs 186112, 503143.75 and 936580.5 . 
very important role in the rural economy of India. It provides income and employment not only to the workers section of the society but also to the farming community of the country in general. The returns from small holding can be maximized by the proper combination of dairy enterprise with crop production. Under the diary enterprise, feed is an important aspect of dairy sector. Fodder accounts up to 45 per cent of the total cost of milk production. Green fodder and dry fodder plays an important role in milk involved of milk, they cannot say with certainty that they will sell their milk at particular price without incurring any loss. If their margin of profit is more because of low cost of production, they may earn good profit and may sell their produce at lower price to catch more market.

\section{Materials and Methods}

The present study was conducted in the Satara district of Maharashtra state during the year of 2018-19.

\section{Sampling plan}

The study was based on the primary as well as secondary data. For the collection of data multistage sampling technique was adopted. The Satara district was purposively selected because it is known for higher milk production in the Western Maharashtra region. In the Satara district two tehsils namely Phaltan and Karad was selected as the cross-breed cows are more concentrated in these two tehsils. From each tehsils three villages was selected randomly. Vasantgad, Sakurdi and Kodoli villages from karad tehsil and Somanthali, Vidni, Sonawadi villages from Phaltan tehsils. The list of farmers having crossbred cow was prepared from six villages. 15 farmers from each village will be selected purposively on the basis of farmers having number of crossbred cow. The respondents are categorised into three categories on the basis of herd size viz Small farmer (1-2 crossbred cow), medium farmer (3-5 crossbred cow) and large farmer 6-10). Thus, 90 Farmers having cross-breed cow was selected.

\section{Cost and return concepts}

Fixed costs: Costs of all fixed assets utilized in milk production i.e. cattle shed, milk cans and other utensils etc.

Variable costs: Costs of feed, fodder, labour charges, veterinary aids, etc.

Total maintenance cost: It was obtained by adding the fixed cost and variable cost.

Gross returns: Total income obtained by the farmer from the total milk sold in the market.

Net return: The value obtained by subtracting the net cost from the gross return.

Net return $=$ Gross return- Net cost

\section{Results and Discussion}

\section{Herd size and operational land holding}

Livestock inventory of sample farmers includes buffalo, cattle, heifer, calves, and goat and poultry birds. The average size of livestock per family at overall level was 9.40. Average total livestock population at Large size group of farmer had 14.18 livestock per farm and Small and medium size group of farmer had 5.02 and 9.02 average number of total livestock. The overall level cow formed 45.65 per cent of the total livestock owned by the farmers. The cow in small size, medium size and large size group was 28.48, 41.79, and 54.12 per cent respectively. The overall level buffalo having 12.98 per cent of the total livestock owned by the farmers. The buffalo in small size, medium size, and large size was 27.81, 14.93, and 6.35 per cent respectively. 
The Average number of poultry at overall level was 6.26. The average number of poultry birds in small, medium and large size group of farmer was 7, 6.56 and 5.23 respectively. The overall level the average size of land holding was 0.96 hectares (Table 1).

The average size of land holding in small, medium and large was found to be $0.71,1.01$ and 1.18 hectares, respectively. The percentage of total area under small, Medium, Large is $24.49,34.82$ and 40.69 respectively. The all area of sample farmers is irrigated. It is observed that the area under large farmers is 1.18 are higher than as compared to small and medium.

\section{Milk production}

The average milk production from the individual milch cow was 12-16 lit per day. The Milk production of cow was various for different herd size. The average total milk production obtained from the small, medium and large size group of farmers was 54215.66 lit. From 54215.66 lit 1406.66 lit (2.59\%) used for family consumption and 52812.71 Lit milk was sold at market (Table 2).

Table.1 Livestock inventory (No/farm)

\begin{tabular}{|c|l|c|c|c|c|}
\hline $\mathbf{S . N .}$ & Livestock & Small & Medium & Large & Overall \\
\hline $\mathbf{1}$ & Cow & 1.43 & 3.73 & 7.66 & 4.27 \\
& & $(28.48)$ & $(41.79)$ & $(54.12)$ & $(45.65)$ \\
\hline $\mathbf{2}$ & Buffaloes & 1.4 & 1.33 & 0.93 & 1.22 \\
& & $(27.81)$ & $(14.93)$ & $(6.35)$ & $(12.98)$ \\
\hline $\mathbf{3}$ & Heifers & 0.3 & 0.33 & 1.03 & 0.55 \\
& & $(5.96)$ & $(3.73)$ & $(7.29)$ & $(5.85)$ \\
\hline $\mathbf{4}$ & Calves & 1.03 & 2.3 & 3.1 & 2.14 \\
& & $(20.53)$ & $(24.63)$ & $(21.88)$ & $(22.76)$ \\
\hline & Goat & 0.86 & 1.33 & 1.46 & 1.2 \\
& & $(17.22)$ & $(14.93)$ & $(10.35)$ & $(12.76)$ \\
\hline & Total livestock & 5.02 & 9.02 & 14.18 & 9.40 \\
& & $(100.00)$ & $(100.00)$ & $(100.00)$ & $(100.00)$ \\
\hline $\mathbf{5}$ & Poultry & 7 & 6.56 & 5.23 & 6.26 \\
\hline
\end{tabular}

Table.2 Disposal pattern of milk (Lit/ Holding)

\begin{tabular}{|c|c|c|c|}
\hline Sr.No & Particulars & Production & Family Consumption \\
\hline 1. & Small & $\begin{array}{r}6183.33 \\
(100.00)\end{array}$ & $\begin{array}{l}414.33 \\
(6.70)\end{array}$ \\
\hline 2. & Medium & $\begin{array}{c}16437 \\
(100.00)\end{array}$ & $\begin{array}{c}441 \\
(2.68)\end{array}$ \\
\hline 3. & Large & $\begin{array}{l}31595.33 \\
(100.00)\end{array}$ & $\begin{array}{l}551.33 \\
(1.74)\end{array}$ \\
\hline 4. & Overall & $\begin{array}{l}18071.88 \\
(100.00)\end{array}$ & $\begin{array}{l}468.88 \\
(2.59)\end{array}$ \\
\hline
\end{tabular}


Table.3 Maintenance cost of crossbreed cow (In Rupees)

\begin{tabular}{|l|c|c|c|c|c|c|c|c|}
\hline Items & $\begin{array}{c}\text { Qty } \\
(\mathbf{K g})\end{array}$ & Small & $\begin{array}{c}\text { Qty } \\
(\mathbf{K g})\end{array}$ & Medium & $\begin{array}{c}\text { Qty } \\
(\mathbf{K g})\end{array}$ & Large & $\begin{array}{c}\text { Qty } \\
(\text { Kg) }\end{array}$ & Overall \\
\hline I. Variable cost & & & & & & & & \\
\hline a) Dry Fodder & 2227.73 & 11138.66 & 5291.9 & 26459.5 & 12095 & 60479 & 6538.21 & 32692.38 \\
& & $(9.26)$ & & $(11.01)$ & & $(11.02)$ & & $(10.43)$ \\
\hline b) Green Fodder & 10540.33 & 31621 & 28522 & 85568.5 & 53849 & 161548 & 30970.44 & 92912.5 \\
& $(26.29)$ & & $(27.24)$ & & $(29.45)$ & & $(27.66)$ \\
\hline c) Concentrate & 1898.63 & 37972 & 5241.73 & 104834.66 & 9713 & 194262.66 & 5617.7 & 112356.44 \\
& $(31.57)$ & & $(33.37)$ & & $(35.41)$ & $(33.45)$ \\
\hline d) Labour Charges & & 14666.66 & & 37110 & & 75066 & & 42280.88 \\
& $(12.19)$ & & $(11.81)$ & & $(13.68)$ & & $(12.56)$ \\
\hline e) V.expenses & & 1956.66 & & 3816.66 & & 12804 & & 6192.44 \\
& $(1.62)$ & & $(1.21)$ & & $(2.33)$ & & $(1.72)$ \\
\hline f) Miscellaneous & & 792 & & 1543 & & 2926.7 & & 1753.9 \\
& $(0.65)$ & & $(0.49)$ & & $(0.53)$ & & $(0.55)$ \\
\hline Total Variable cost & & 98147.66 & & 259309 & & 433781 & & 263745.88 \\
& $(81.60)$ & & $(82.56)$ & & $(79.09)$ & & $(81.09)$ \\
\hline II. Fixed cost & & Small & & Medium & & Large & & Overall \\
\hline a) Depreciation on & & 11623.2 & & 28734.62 & & 60227.09 & & 33528.30 \\
Animal, Byre, Utensils & & $(9.67)$ & & $(9.12)$ & & $(10.98)$ & & $(9.92)$ \\
\hline Interest on fixed capital & & 10503.94 & & 26037.50 & & 54473.76 & & 30338.4 \\
& & $(8.74)$ & & $(8.29)$ & & $(9.93)$ & & $(8.98)$ \\
\hline Total fixed cost & & 22127.15 & & 54772.12 & & 114701.2 & & 63866.82 \\
& $(18.40)$ & & $(17.44)$ & & $(20.91)$ & & $(18.91)$ \\
\hline Total maintenance cost & & 120274.82 & & 314081.12 & & 548482.73 & & 327612.89 \\
& & $(100)$ & & $(100)$ & & $(100)$ & & $(100)$ \\
\hline Value of dung (Rs.) & 4485.5 & 6728.25 & 12844.83 & 19267.25 & 25245 & 37867.5 & 14191.77 & 21287.66 \\
\hline Net maintenance cost & & 113546.57 & & 294813.87 & & 510615.23 & & 306325.22 \\
& & $(94.40)$ & & $(93.86)$ & & $(93.09)$ & & $(93.50)$ \\
\hline Per liter maintenance & & 18.36 & & 17.99 & & 16.16 & & 17.50 \\
cost of cow & & & & & & & & \\
\hline
\end{tabular}

Table.4 Cost and return structure for cow milk production (₹/ cow/year)

\begin{tabular}{|c|c|c|c|c|c|c|c|c|}
\hline \multirow[t]{2}{*}{ Returns } & \multicolumn{2}{|c|}{ Small } & \multicolumn{2}{|c|}{ Medium } & \multicolumn{2}{|c|}{ Large } & \multicolumn{2}{|c|}{ Per cow } \\
\hline & Qty (Kg) & $\begin{array}{c}\text { Value } \\
\text { (₹) }\end{array}$ & Qty (Kg) & $\begin{array}{c}\text { Value } \\
(₹)\end{array}$ & Qty (Kg) & $\begin{array}{c}\text { Value } \\
(₹)\end{array}$ & Qty (Kg) & $\begin{array}{c}\text { Value } \\
(₹)\end{array}$ \\
\hline 1. Milk & 6183.33 & $\begin{array}{c}176680.83 \\
(94.93)\end{array}$ & 16437 & $\begin{array}{c}478166.5 \\
(95.00)\end{array}$ & 31595.37 & $\begin{array}{c}890979.66 \\
(95.13)\end{array}$ & 4206.02 & $\begin{array}{l}119924 \\
(95.07)\end{array}$ \\
\hline 2.dung & 4485 & $\begin{array}{c}6728.25 \\
(3.76)\end{array}$ & 12844.83 & $\begin{array}{c}19267.25 \\
(3.85)\end{array}$ & 25245 & $\begin{array}{c}37867.5 \\
(4.04)\end{array}$ & 3302.93 & $\begin{array}{c}4954.46 \\
(3.92)\end{array}$ \\
\hline 3.Offspring & & $\begin{array}{c}2433.33 \\
(1.30) \\
\end{array}$ & & $\begin{array}{c}5443.33 \\
(1.15)\end{array}$ & & $\begin{array}{c}7600 \\
(0.83) \\
\end{array}$ & & $\begin{array}{c}2120 \\
(1.68)\end{array}$ \\
\hline Total returns & & $\begin{array}{c}186112 \\
(100)\end{array}$ & & $\begin{array}{c}503143.75 \\
(100)\end{array}$ & & $\begin{array}{c}936580.5 \\
(100)\end{array}$ & & $\begin{array}{c}126131.59 \\
(100)\end{array}$ \\
\hline $\begin{array}{l}\text { Total } \\
\text { Maintenance cost }\end{array}$ & & 120274.82 & & 314081.12 & & 548482.73 & & 76248.15 \\
\hline Net returns & & 65837.59 & & 189029.28 & & 506148.96 & & 59039.24 \\
\hline B: C Ratio & & 1.54 & & 1.61 & & 1.70 & & 1.65 \\
\hline
\end{tabular}




\section{Maintenance cost}

In the table 3 it is observed that, the overall level, per cow cost of maintenance was $327612.89 ₹$. Total variable cost for small size group farmers was ₹ 98147.66 (81.60 \%), for medium size group of farmer was ₹ 259309 $(82.56 \%)$, and ₹42018 (74.80\%) for large size group of farmer was ₹433781 (79.09\%). The Variable cost was more for medium size group of farmers as compared to large and small size group of farmers.

For the different items of the cost of maintenance Concentrate was the major item of the cost and which accounted for ₹112356.44(33.45 \%), followed by green fodder accounted for ₹92912.05 (27.66\%), dry fodder ₹32692.38(10.43\%), labour charges ₹ 42280.88 (12.56 \%), veterinary expenses were ₹ $6192.44 \quad(1.72 \%)$, miscellaneous cost for overall level was $₹ 1753.9(0.55 \%)$. Total variable cost required $₹$ 263745.88(81.09). The total fixed cost required for the cross-bred cow maintenance was ₹63866.52 which was 18.91 percent of the total cost. The total fixed cost includes Interest on Fixed capital (Animal, shed/Byre, Utensils) was ₹33528.30 (9.92\%), followed by cost on depreciation on fixed capital which was ₹30336.4 (8.98\%)

The fixed cost per cow maintenance for small, medium and large size group of farmer was $22127.15(18.40 \%), \quad 54772.12 \quad(17.44 \%)$ $114701.20(20.91 \%)$ respectively. Fixed cost was more for large size group of farmer as compared to large group and Small group of farmers.

Per cow total maintenance cost for small medium and large size group of farmer was $120274.82, \quad 314081.12$, and 548482.73 respectively. Total maintenance cost was more for large size group of farmers as compared to small and medium size group of farmers. Value obtained from dung at overall level was 21287.66 and for small medium and large size group of farmer was 6726.25, 19267.28 and 37867.50 respectively.Net maintenance cost for overall level was 306325.22, which is obtained by subtracting the value of dung from total maintenance cost.Net maintenance cost for small size group of farmer as compared to large and medium size group of farmers.

The input cost was higher for small size group of farmer followed by medium and large size group farmer.

\section{Gross return}

The annual gross returns obtained from the crossbreed cow milk include the value of milk, dung, and offspring. Table 4 shows the cost and return obtained from the crossbreed cow was depends on the breed category, feeding, breeding, and management practices and the environment. The returns from the milk were calculated on the basis of average quantity of milk yield per cow and average price received per liter of milk. Dung is useful waste. It is used as fuel and manure. Return from cow dung was considered by taking average price at which dung was sold in the study area. The value of offspring was taken on the basis of actual market price received in the market for offspring.

Per cow cost of maintenance per annum on selected farm was calculated by adding the value of variable cost and fixed cost together. Estimating value of milk, value of dung/ manure and value of calf up to one year and per animal returns, was calculated and presented in Table 4.

For the per cow, the total maintenance cost of cross-bred cow was 76248.15, and gross returns obtained was Rs. 126131.59 out of which 95.07 per cent was received from milk, 
3.92 per cent from dung and 1.68 per cent was value of Calves. Net return obtained from cross-bred cow milk production was Rs. 59039.24 .

The benefit: cost ratio in cross-bred cow milk production was calculated by dividing gross income to total cost. In the table 4 It is observed that, $\mathrm{B}: \mathrm{C}$ ratio in cross-bred cow milk production was 1.65 at overall level which showing that by investing $1 \mathrm{Rs}$ in crossbreed cow milk production, a net returns of 0.65 were earned by farmers. The B: C ratio for small, medium and large size group of farmer was 1.54, 1.61 and 1.70. Therefore the cross-bred cow milk production was more profitable business for large size group farmers than the medium and small size group of farmers.

The study was concluded that the variable cost was most important in maintenance cost of crossbreed cow. In the total maintenance cost variable cist was 81.09 per cent and fixed cost was 18.91 per cent. In variable cost most important item was concentrate and green and dry fodder. The gross return obtained for respondent farmer was different for various categories. It is depend on the herd size. The highest gross return obtained by the large size of group of farmers.

\section{References}

Kolekar, P.L., Changule, R.B., Mane, B.B., Mane, U.S. and Gharge, S.H. (2011). Economic analysis of milk production in different sizes of dairy units in Pune district of Maharashtra, Research Journal Animal Husbandry \& Dairy Science, 2(1\&2) : 34-36.

Kumar, M., Dhillon, A. and Luhach, V.P. (2015). Economic analysis of milk production in Rewari district of Haryana. Indian Journal of Dairy Science, 68(5): 496-501.

Kumar, N., Tkui, K., Tegegne, D. T. and Mebratu, A.T. (2014). Productive Performance of Crossbred Dairy Cows and constraints faced by dairy farmers in Mekelle, Ethiopia. IOSR Journal of Agriculture and Veterinary Science, 7(1): 62-66.

Kumar, R. and Tripathi, H. (2011). Profitability of Cross Breeding among the Dairy Farmers. Indian Research. Journal of Extension Education, 11(1): 32-38.

\section{How to cite this article:}

Jadhav, S. L., K. V. Deshmukh and Shelke, R. D. 2020. Economic Analysis of Milk Production in Satara District of Maharashtra. Int.J.Curr.Microbiol.App.Sci. 9(11): 2487-2492. doi: https://doi.org/10.20546/ijcmas.2020.911.300 